\title{
Staying in place during times of change in Arctic Alaska: the implications of attachment, alternatives, and buffering
}

\author{
Henry P. Huntington ${ }^{1}$ (D) P Philip A. Loring ${ }^{2} \cdot$ Glenna Gannon $^{2} \cdot$ Shari Fox Gearheard $^{3}$. \\ S. Craig Gerlach ${ }^{4} \cdot$ Lawrence C. Hamilton $^{5}$
}

Received: 2 March 2017 / Accepted: 31 August 2017 /Published online: 19 September 2017

(C) The Author(s) 2017. This article is an open access publication

\begin{abstract}
The relationship between stability and change in social-ecological systems has received considerable attention in recent years, including the expectation that significant environmental changes will drive observable consequences for individuals, communities, and populations. Migration, as one example of response to adverse economic or environmental changes, has been observed in many places, including parts of the Far North. In Arctic Alaska, a relative lack of demographic or migratory response to rapid environmental and other changes has been observed. To understand why Arctic Alaska appears different, we draw on the literature on environmentally driven migration, focusing on three mechanisms that could account for the lack of response: attachment, the desire to remain in place, or the inability to relocate successfully; alternatives, ways to achieve similar outcomes through different means; and buffering, the reliance on subsidies or use of reserves to delay impacts. Each explanation has different implications for research and policy, indicating a need to further explore the relative contribution that each makes to a
\end{abstract}

Editor: Jamie Pittock.

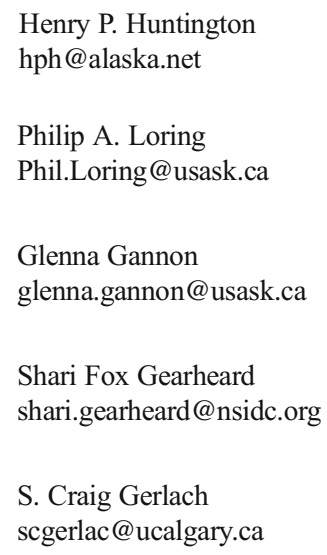

given situation in order to develop more effective responses locally and regionally. Given that the Arctic is on the front lines of climate change, these explanations are likely relevant to the ways changes play out in other parts of the world. Our review also underscores the importance of further attention to the details of social dynamics in climate change impacts and responses.

Keywords Climate change $\cdot$ Resilience $\cdot$ Environmental security $\cdot$ Migration $\cdot$ Adaptation

\section{Introduction}

The relationship between stability and change in socialecological systems has long received attention in academic research, most recently through such lenses as resilience, vulnerability, adaptation, and sustainability (e.g., Holling 1973; Bennett 1976; Bates 2004; Gallopín 2006; Huntington et al.
Lawrence C. Hamilton

Lawrence.Hamilton@unh.edu

Huntington Consulting, 23834 The Clearing Dr, Eagle River, AK 99577, USA

2 School of Environment and Sustainability, University of Saskatchewan, Saskatoon, SK S7N 5C8, Canada

3 National Snow and Ice Data Center, University of Colorado Boulder, Boulder, CO 80309-0449, USA

4 Department of Anthropology and Archaeology, University of Calgary, Calgary, AB T2N 1N4, Canada

Department of Sociology, University of New Hampshire, Durham, NH 03824, USA 
2007; Kates 2011; Fazey et al. 2017). Generally, this research is concerned with how social and environmental changes are experienced at some level, whether a person, household, or remote, natural resource-dependent community: when pressed, do key features of these systems change, or stay the same, and why? How can we use this knowledge to help people prepare for change? A reasonable premise in this work is that changes that reduce or compromise people's environmental security ${ }^{1}$ will motivate people to respond in some discernable fashion (Hamilton et al. 2004; Marina et al. 2011; McClanahan and Cinner 2011; Loring et al. 2013), albeit in ways that are mediated by numerous societal factors and dynamics, from socioeconomic status to the flexibility of local institutions (Hamilton et al. 2004; Haynie and Huntington 2016).

Mobility and migration, which describe short- and longterm movements of people for any number of reasons, is one commonly observed example of how people respond to environmental variability and change (Black et al. 2011; Thornton and Manasfi 2010). Rapid and large-scale migration, for example, has been observed in the Kola Peninsula, Russia, during the collapse of the Soviet Union (Voinov et al. 2004), in various regions around the North Atlantic in response to fisheries declines (Hamilton and Haedrich 1999; Hamilton et al. 2004; Hamilton 2007; MacDonald et al. 2012), and in rural Spain following the phylloxera wine blight (Steevenson 2004). Likewise, extreme events such as fire, drought, or other natural disasters often lead to short-term migration, and in the most severe cases, result in refugeeism (Biermann and Boas 2010). The current and future impacts of climate change are likewise widely expected to drive new patterns of human migration, displacement, and refugeeism throughout the world (Adger et al. 2014). The term "climigration" was coined to capture the specific political ecology of forced migration due to rapid, climate change-driven environmental changes (Bronen 2009).

Rural communities in Alaska, where environments are changing rapidly because of climate change (Chapin et al. 2014), are among those that have been identified as likely locales for climigration. A recent analysis of 43 predominantly indigenous communities in Arctic Alaska, however, found no evidence of enhanced outmigration from the communities most threatened by climate-linked impacts, as well as no evidence of a demographic response to other challenges, such as spikes in fuel price or an economic recession (Hamilton et al. 2016). Rather, the populations of many of these communities are growing, as high birth rates more than offset outmigration. So, while outmigration remains high for many of these arctic communities, the study by Hamilton et al. suggests that it is

\footnotetext{
${ }^{1}$ As used here, environmental security includes food, water, and energy security as well as the security of one's person, physical environment, quality of life, health, and well-being (c.f., Loring et al. 2013; Grumbine 2014).
}

not responsive to either the rapid environmental changes caused by climate change or other socioeconomic stressors in the same way as has been observed elsewhere. It is of course possible that the environmental changes experienced by Arctic Alaska communities have, so far, not materially reduced their environmental security, creating no need for a migratory or other response; but such an interpretation contradicts many statements and other evidence of rising impacts and challenges for Arctic Alaska residents (e.g., Bronen 2009; Brinkman et al. 2014; Marino 2015; Huntington et al. 2016).

Others have explored the various interacting social and ecological drivers that can result in changing migration patterns (e.g., Black et al. 2011; McLeman and Smit 2006; McLeman 2014). Here, we consider mobility from the opposite perspective - how and why do people stay? We review some possible explanations for the lack of apparent demographic response to environmental changes in Arctic Alaska and their implications for research and policy concerning the impacts of climate change on natural resource-dependent communities. The basic idea that we explore, that social dynamics can complicate and even obscure ongoing impacts from a loss of environmental security, is not in and of itself new (e.g., Oliver-Smith 2013), but the framework we present here offers new insights into the distinct elements of these social dynamics, and as such, has application well beyond the Arctic.

\section{Background}

Mobility, as used here, "entails the freedom to seek opportunities to improve living standards, and health and education outcomes, and to live in safer, more responsive communities" (UNDP 2010, p.1). Migration, a closely related concept, describes any number of patterns of movements by people, whether short- and long-term, willing or forced. It is generally recognized that changing environmental conditions, especially those that impact local livelihoods, can influence people's mobility and migration decisions (Hunter 2005, Black et al. 2011, Huntington et al. 2012, Hunter et al. 2015). Myers (2002) estimated that by the end of the twentieth century there were nearly as many "environmental" refugees in the world as there were refugees from political, economic, or religious persecution. There is also ample historical and recent empirical evidence of environmentally driven migration. Hurricane Katrina displaced a significant number of people within the southern United States (Fussel and Elliott 2009). Some migration was short-term, while others were displaced from their homes permanently; some people also immigrated to the region during and after the response and recovery period, capitalizing on the spaces left by those who did not or could not return. The collapse of cod fisheries in the North Atlantic 
also gave rise to a noteworthy amount of migration. Hamilton and Haedrich (1999) identified a tight coupling of population changes and codfish landings in both the Faroe Islands and Greenland. When cod fisheries were strong or expanding, populations rose; as cod fisheries declined, so did populations, except in cases where communities had viable fishing alternatives, specifically shrimp.

This latter point about the availability of alternative resources raises the issue that single drivers of environmental change are rarely sufficient to explain migration trends. Both observational and model-based researches into environmentally driven migration show that numerous different social and cultural considerations can mediate demographic responses to environmental and economic declines (e.g., MacDonald et al. 2012; Entwisle et al. 2016). In the case of Newfoundland cod fisheries, migration has been shown to involve a complex tapestry of mobility strategies and diverse social, cultural, and economic incentives (MacDonald et al. 2012). Likewise, in an agent-based modeling exercise, Entwisle et al. (2016) show that climatic changes have comparatively weak effects on migration when compared with the effects of social networks and opportunities for adaptation.

Black et al. (2011) propose a conceptual framework for capturing these diverse influences on environmental migration, emphasizing political, demographic, economic, and social drivers that, at the macroscale, collectively come to bear on people's decisions to stay or leave when faced with some environmental challenge. Their framework identifies mesoscale factors such as social networks and the costs of moving, as well as microscale factors including household characteristics and education levels. They note that migration happens on a spectrum, from mobility on the one hand, which involves planned and proactive moves, to displacement on the other. Finally, they also make the observation that communities and societies are generally always experiencing some degree of migration (see also Carr 2005; MacDonald et al. 2012), meaning that studies of the role of environmental change must focus on net changes in these ongoing patterns of mobility and displacement. These observations resonate in Arctic Alaska, which has long been characterized by both shortand long-term migrations for such reasons as jobs, healthcare, and fishing and hunting practices (Hamilton and Seyfrit 1994; Huskey et al. 2004; Howe et al. 2014; Hamilton et al. 2016).

Migration as a response to environmental change has also been discussed from the perspectives of resilience and adaptation. At the most basic level, resilience describes the ability of a system to return to its former state after experiencing some stress or injury (Holling 1973), and adaptation refers to the processes by which people enact strategies in response to change that, if adopted widely, accumulate as "patterned deviations" in behavior, culture, and society (Bennett, 1996; Bates 2004) The concept of social-ecological resilience marries the two, also incorporating the notion of transformation, in an attempt to fully characterize stability and change in social-ecological systems (Walker and Salt 2012; Fazey et al. 2017). Within this resilience thinking framework, social-ecological systems are said to be resilient if they can absorb, recover from, or otherwise adapt to change and surprise (Walker et al. 2006). Social-ecological resilience is thus not anchored to discrete stable states or thresholds in the same way as ecological resilience, but instead, emphasizes key system dynamics and parameters that people consider important to their individual and collective identities (Cumming and Collier 2005). As such, whether people stay or move is not uniformly indicative of resilience or lack thereof. That is, both staying and moving could be interpreted as signs of resilience. For example, short-term, seasonal mobility among arctic peoples has been identified as a strategy that historically conferred resilience to household and communities faced with environmental variability and change (Kofinas et al. 2016). Conversely, for the above-noted cases regarding North Atlantic cod fisheries, evidence of migration following fisheries collapse has been interpreted as a lack of resilience (Arctic Council 2016).

Migration as adaptation has also been explored in the contemporary literature on climate change (Adger et al. 2005, 2016; Ford et al. 2015). This literature borrows from, but is different in focus from, the literature on behavioral and cultural adaptation (Bennett 1996; Bates 2004; Thornton and Manasfi 2010). Whereas the latter focuses on changes that accrue over time, climate change adaptation is a more anticipatory and planning-oriented concept. That is, from the perspective of human adaptation theory, mobility is an adaptive strategy, whereas the patterns of settlement and migration that result may or may not be considered adaptations. In the climate change adaptation literature, just about any response that people mount to climate change has been considered an adaptation, regardless of whether the outcomes are beneficial (adaptive) or detrimental (maladaptive) in the long run (Thornton and Manasfi 2010; Barnett and O'Neill 2010). Thus, neither the social-ecological resilience nor the climate change adaptation framework captures sufficient information to evaluate mobility patterns as normatively good or bad, whether from a health, policy, or social justice perspective (Thornton and Manasfi 2010; Standish et al. 2014; Loring et al. 2016).

As with the literature on migration, both resilience and adaptation literatures identify a host of interacting social, economic, and ecological factors from the availability of different forms of capital to social institutions such as sharing and learning (Walker and Salt 2012). So many different social and ecological factors have been suggested as potentially important to resilience and adaptation, that the entire framework has been critiqued as unworkable, except as bridging language for discussing patterns of response (Brand and Jax 2007; Alexander 2013; Feola 2015). Likewise, numerous issues 
have been raised with the literatures on adaptation and socialecological resilience from circular and inconsistent definitions of the concepts to the problematic application of ecological metaphors to social systems (Davidson 2010; Thornton and Manasfi 2010; McGreavy 2015). Collectively, these issues inform our motivation to develop a framework that, while similar and complementary to these research programs in a number of ways, does not begin with the same system-level approach and assumptions.

\section{Explaining a lack of change}

We are interested here in exploring causality with respect to migration, that is, what causes individuals to act in such a way that results in community- or regional-level patterns of demographic change. Explaining causality in social systems is challenging and requires the development of "best fit" explanations through the comparison of several hypotheses for both what did and what did not happen (Bateson 1967; Vayda and Walters 2011).To this end, we present a conceptual framework based on three categories of explanations for how and why people stay: attachment, alternatives, and buffers.

- Attachment, or staying despite apparent discomfort, loss of income, or other negative outcomes of decreased environmental security. Sometimes called place attachment or community attachment (Trentelman 2009), evidence of attachment can include expressions of the importance of place and community to identity, though attachment can ironically motivate people to stay despite negative consequences to their health. Attachment can therefore be a positive attribute in the sense of being committed to a place during a time of hardship, or it can be a negative attribute in the sense of having no better options or being "locked in" (e.g., Allison and Hobbs 2004; Barnett and O’Neill 2010).

- Alternatives, or making small-scale changes that maintain health and economic status despite decreased environmental security, ideally leading to long-term solutions to recurrent challenges. Note that alternatives are generally not pursued for the purposes of change but for maintaining stability, and could also be termed "adaptive strategies" (Thornton and Manasfi 2010). Evidence of alternatives includes changes that produce positive outcomes and expressions of confidence and optimism regarding the future. Alternatives are generally a positive attribute, to the extent that they draw on innovation and other forms of local capacity to sustain or improve quality of life and so long as the changes do not contradict community norms (Huntington et al. in revision).

- Buffering, or drawing on external or reserve resources to absorb impacts and delay negative consequences (Byron
2003). Evidence of buffering includes high reliance on external support (e.g., subsidies), a decrease in reserves, expressions of temporary fixes, and declines over time of capacity to respond to surprise (Penn et al. 2016). Buffering, as we use it here, is similar to the original notion of ecological resilience, but it also accounts for the notion that buffers can be depleted over time. People have tremendous ability to sustain themselves and maintain a positive outlook on life despite objectively poor circumstances (Diener 2009), though this kind of endurance can only be stretched so far. Buffering can therefore also be a positive attribute if the buffers allow a community to endure and recover from some short-term stressors and can be replenished, or a negative attribute if buffers allow problems to worsen or are exhausted before problems are acknowledged and alternatives can be created.

Examples of attachment, alternatives, and buffering from Arctic Alaska are given in Table 1. These three categories of explanation mirror concepts from social-ecological resilience theory - resilience (the ability to withstand shocks), potential (the resources or capital available for response), and connectedness (the internal controls in a system that influence its sensitivity to perturbation). An important difference in how we use them is that we are focusing on factors that inform individual decisions, whereas potential, connectedness, and resilience are systems-level properties. For instance, a socialecological system could be described as having some level of connectedness because of existing social institutions for sharing and maintaining traditions, but different people within that system may feel different levels of attachment to place, have different degrees of access to different social capital and networks, or may or may not choose to leverage those resources. Downscaling these concepts also helps to address the challenge noted above that a system-level view can miss normative details regarding the health and social justice implications of being forced to be resilient or to adapt to change.

Below, we narrate what these ideas might look like in action, drawing on the well-documented example of a sharp rise in fuel prices, as was experienced across rural Alaska in 2008 (Brinkman et al. 2014). An important observation is that these three categories are not mutually exclusive or competing. Elements of each are likely to be found in most patterns of responses to change, though their relative balance can vary. Then, we discuss the implications of these three categories of explanations for communities and what they indicate for research and policy needs. The sections below are speculative in nature; to illustrate how these concepts support the identification of multiple possible hypotheses, all of which must be explored to better identify causality of broader patterns of outcomes (Vayda and Walters 2011). Because the Arctic is experiencing the effects of climate change earlier and in a more amplified manner than many other locales (Serreze and 
Table 1 Examples of the evidence that would support the explanations of attachment, alternatives, and buffering in rural Alaska

\begin{tabular}{lll}
\hline Attachment & Alternatives & Buffering \\
\hline $\begin{array}{l}\text { Staying despite loss of income, } \\
\text { living standard }\end{array}$ & $\begin{array}{c}\text { Shifting among subsistence and commercial } \\
\text { species }\end{array}$ & Subsidies (postal, fuel, power, housing, food ...) \\
$\begin{array}{l}\text { Moving back after leaving for another place } \\
\text { Dietary and environmental health impacts } \\
\text { Statements about the importance of place }\end{array}$ & $\begin{array}{c}\text { Cost-cutting (e.g., purchasing cheaper food, } \\
\text { using Amazon Prime or online suppliers } \\
\text { offering free shipping) }\end{array}$ & $\begin{array}{l}\text { Postponing new purchases or maintenance } \\
\text { Local organizations/services (e.g., food banks, school } \\
\text { breakfast/lunch programs) }\end{array}$ \\
& & $\begin{array}{c}\text { Release valve (moving temporarily to city or to other rural } \\
\text { community where people have some additional forms } \\
\text { of support) }\end{array}$ \\
\end{tabular}

Barry 2011; Markon et al. 2012), these arctic communities' experience of climate change may be a precursor for communities elsewhere. Our observations are therefore likely to be relevant to situations in other geographic and sociocultural locales as well.

\section{Attachment, alternatives, and buffering in practice}

Staying in place, because of attachment, involves people finding one or more ways to deal with the impacts of higher fuel prices, which affect heating, electricity, and transportation, the last of which also affects people's ability to access wild fish and game. High poverty levels in rural Alaska suggest that, for most households, an increase in expenditures on fuel will mean less money for other necessities such as food, with consequent impacts on well-being (Fazzino and Loring 2009; Gerlach et al. 2011). Another possible response is to reduce fuel use, for example, by lowering the temperature to which one's house is heated, or reducing metered water use, which also saves money. But such options may also reduce people's overall well-being.

Alternatives, in this example, could include temporary migration for short-term or seasonal work (Huskey et al. 2004; MacDonald et al. 2012), or pooling of resources for transportation, as some hunters do by coordinating and consolidating hunting parties (Magdanz et al. 2002; Brinkman et al. 2014; Kofinas et al. 2016). A change such as this can be seen as a positive response, in that people are relying on local capacity for innovation and cooperation. Such a change may have negative consequences, too, such as the exclusion of some potential hunters, including younger ones who may lose the chance to develop necessary skills, or marginalization of people who do not belong to such sharing networks. The strategy may cease to be effective if fuel prices continue to rise, because the underlying problem of high fuel prices relative to local purchasing power has not been altered. Alternatively, other options may be more dependable in the long run, such as a switch to locally available biofuels for heating or wind power for generating electricity.

Buffering involves finding a way to create at least shortterm insulation from the impacts of higher fuel prices. The lack of demographic response to high fuel prices could mean that fuel prices are not a major factor in the decisions of rural residents, for example, if heating oil is provided through subsidy programs so that a price increase does directly affect individuals. Such a buffer-by-subsidy is useful only to the extent that the subsidy continues. Buffers contribute to sustainability only if they can be sustained or replenished, but not if they simply incur long-term deficits. For instance, women in households will often reduce how much they consume so that children can eat, known as maternal buffering (Maxwell et al. 1999). This is not a sustainable strategy in that it will erode the women's physical health over time. In addition, individual or community psychological resilience may serve as a bufferpeople have an ability to normalize objectively poor circumstances (Deiner 2009), and this may work in tandem with "attachment" to motivate people to endure or even accept bad circumstances.

Few individuals or communities are likely to exhibit characteristics of only one explanation, and indeed, alternatives and buffering can be seen as strategies to support attachment, the strength of which may determine greater or lesser motivation for using such strategies instead of moving elsewhere. One might turn down the heat at home, spend a month fighting forest fires outside the community, or join a collaborative hunting group to keep one's lifestyle intact and to stay in one's home for the time being. The availability of different strategies will also vary with location and circumstance. For example, the use of Amazon Prime and its free shipping (Zak 2015) to obtain goods at competitive prices is an effective alternative for rural Alaska residents, but one that depends on the subsidy or buffer of government support for rural mail delivery. This buffer does not exist in the same way in Nunavut, Arctic Canada, with the result being that Amazon Prime with its role as an alternative is unavailable in most Nunavut communities due to the much higher cost of postage (Rogers 2015). 
The three explanations of attachment, alternatives, and buffering can work together through complex feedbacks and interactions in positive ways. For example, BurnSilver et al. (2016) recently explored the relative stability of the so-called mixed cash-subsistence economy in Alaska. They found that strong cultural attachment and buffering of individual hardships through food sharing have contributed to the persistence of this hybrid economic system. Further, the hybrid system itself likely creates something of an economic portfolio, making people resilient to short-term spikes in fuel cost because they have a system of alternatives for making ends meet.

These three explanations can also combine in unsustainable ways. One example is the so-called nutrition transition occurring across the rural North, including Alaska (Kuhnlein et al. 2004; Loring and Gerlach 2009), which describes a slow progression of diets from subsistence foods to lower-quality market foods. Driven in part by climate change but also because of economic challenges and legacies of colonialism (Loring and Gerlach 2015), rural community residents are drawing on market foods to meet short-term needs. Because these are of lower nutritional quality than traditional foods, health suffers, as clearly shown by epidemic levels of dietary health challenges such as obesity and diabetes in indigenous populations (ADHSS 2016; CDC 2003). Other psychosocial challenges such as suicide are also at epidemic levels in rural Alaska, and these are likewise linked to the complex and changing social-ecological milieu in which the nutrition transition is taking place (Allen et al. 2014, 2016). People, then, either cannot or will not leave (attachment), substitute less healthy foods for healthy ones (alternatives), and bear impacts which include deterioration of long-term health (erosion of a buffer), an outcome that may not typically be understood as a consequence in part of environmental change. The extent to which rural populations can continue to bear the health and other burdens associated with the social, economic, and ecological challenges is an open question.

\section{Discussion}

Attachment, alternatives, and buffering, especially when acting together, offer possible explanations of the apparent lack of "climigration" or migration due to economic stressors in Arctic Alaska. Collectively, they align with aspects of socialecological resilience and they add an important level of detail for how system-level parameters (i.e., connectedness, potential, resilience) manifest in individual people's decisions. These three explanations are not interchangeable and are not always positive in terms of supporting health and well-being (e.g., the difference between being committed to a place and being "locked in"). Each explanation likewise has different implications for the sustainability and well-being of the community in question in both the short and long term.
A failure to distinguish one explanation from others, or take into consideration the compounding effects of interacting mechanisms, can potentially lead to counterproductive actions and policies. Table 2 provides a summary of how the three mechanisms may indicate a community's assets and deficiencies, along with the risks of ignoring these mechanisms when they are in action. In combination with the policy implications discussed in the next section, the differences between attachment, alternatives, and buffering suggest the perils of confusing them and the way they function. Attachment, for instance, could be mistaken for alternatives if one assumes that staying in place is an affirmative choice with no impacts rather than one that is imposed by lack of available capital. Similarly, the use of a buffer may appear to produce short-term results similar to those possible through finding alternatives, though the erosion of the buffer may be overlooked, leading to long-term deficits. Finally, they can interact; eating store-bought food when there is a shortage of subsistence foods, for example, is an example of people using alternatives, but using these alternatives can deplete buffers such as physical and psychological health and cultural heritage if enacted too frequently and for too long (Loring and Gerlach 2009).

It is also important to acknowledge that the three mechanisms can serve different roles at different scales. For example, when a person loses a job, buffers may operate at a local or regional level (e.g., food banks) by providing short-term assistance while individuals explore livelihood alternatives. Individuals may ultimately choose to relocate for a job, or attachment may keep her or him in the community. In the case of the latter, the use of such a buffer could prove positive if the individual discovers a fruitful alternative (e.g., starting a business), but if she or he becomes dependent on the buffer (i.e., the food bank), the community's collective capacity to cope with future challenges (e.g., more unemployed people) is diminished. In other words, if one assumes that no increase in outmigration means that there is no negative impact worth addressing, one risks overlooking "invisible losses" that are important environmental injustices (Turner et al. 2008; Loring 2013).

\section{Research and policy concerning remote communities}

"Sustainability" by one term or another has long been held as a desirable goal. It typically implies achieving well-being in the present without compromising the potential for attaining well-being in the future (e.g., WCED 1987). With attachment, alternatives, and buffering in mind, the concept of sustainability becomes more complicated because stability at one scale or level of organization may indicate injustices or unsustainable problems at another. Attachment may stem from and foster cultural integrity, but it can also be maladaptive in the sense that it compromises people's health and well-being. Finding new and innovative alternatives is an ongoing need that many communities in the North and elsewhere are actively pursuing, 
Table 2 Assets, deficiencies, and risks associated with attachment, alternatives, and buffering

\begin{tabular}{|c|c|c|c|}
\hline & Attachment & Alternatives & Buffering \\
\hline Assets drawn on & Commitment to place, place identity & Range of abilities, flexibility & $\begin{array}{l}\text { Ability to create and/or take advantage of } \\
\text { buffers, use them judiciously }\end{array}$ \\
\hline $\begin{array}{l}\text { Deficiencies (possibly) } \\
\text { revealed }\end{array}$ & $\begin{array}{l}\text { Unwillingness to change, } \\
\text { inability to change }\end{array}$ & Lack of continuity, instability & $\begin{array}{l}\text { Lack of long-term strategy } \\
\text { Dependence on subsidies }\end{array}$ \\
\hline Risks if ignored & $\begin{array}{l}\text { Conceals suffering, delays and } \\
\text { exacerbates harm }\end{array}$ & $\begin{array}{l}\text { Conceals instability and allows } \\
\text { invisible losses }\end{array}$ & Delays impacts and motivations for adaptation \\
\hline
\end{tabular}

the details of which cannot be predicted or relied upon since innovation, by definition, means doing something new and previously unforeseen. Buffering is necessary to weather short-term fluctuations and shocks, but in the long term, buffers can be depleted, producing dependence on the buffering strategy and stifling future adaptive response.

In research terms, more work is needed to distinguish, evaluate, and understand the respective roles of attachment, alternatives, and buffering with regard to demographic change and long-term sustainability at and across various organizational levels and temporal and spatial scales. This includes developing means to measure and monitor indicators of each category of explanation, as well as improving our understanding of the interplay among all three mechanisms. To that end, we believe that these three concepts will be useful for designing qualitative social research, offering a language that resonates with local people but that also links to broader frameworks like resilience. It will also support studies that merge various disciplines to consider the diverse ethnographic, economic, policy, and health aspects of impacts and responses to environmental changes (see Table 3). Research along these lines would be a noteworthy contribution to the work on climate change adaptation, which has been critiqued for misunderstanding the motivations that underlie people's responses to change (Thornton and
Manasfi 2010; Loring et al. 2016). Such research should of course be done in close collaboration with members of the communities in question, both to apply their insights when developing hypotheses and interpreting data and to better find ways to use the results for the community's benefit.

The recognition of attachment, alternatives, and buffering could also lead to more focused policy actions and strategies that encourage lasting, locally appropriate adaptation strategies rather than shifting the burden of impacts to communities that have few choices other than to withstand whatever comes their way. Whether people stay in a place because they are locked in or because they have no desire to leave will influence the relative ability of policy to help create healthful and sustainable outcomes (see Table 4). Buffering in particular should be recognized for what it is - a means of smoothing the bumps in the road rather than putting off hard decisions. Buffers can enable people to bridge a time of troubles, allow time for people to experiment with alternatives, and achieve a more sustainable and desirable outcomes in the long run. Alternatively, they can mask the fact that a situation is unsustainable so that impacts are not recognized or needed changes enacted. The suite of economic, social, cultural, and environmental factors that shape the lives of rural communities and their residents in Alaska is likely to change substantially in the

Table 3 Research needs to explore attachment, alternatives, and buffering

\begin{tabular}{|c|c|c|c|}
\hline Attachment & Alternatives & Buffering & Overall \\
\hline $\begin{array}{l}\text { Ethnography to better } \\
\text { understand individual } \\
\text { decisions to stay in, leave, } \\
\text { or return to a community }\end{array}$ & $\begin{array}{l}\text { Ethnography to better understand } \\
\text { choices, sharing of ideas and } \\
\text { resources }\end{array}$ & $\begin{array}{l}\text { Ethnography to assess awareness of } \\
\text { buffers and how people use them }\end{array}$ & $\begin{array}{l}\text { Ethnography to better understand how } \\
\text { people use the components of the system } \\
\text { to their advantage and also what barriers } \\
\text { they find }\end{array}$ \\
\hline $\begin{array}{l}\text { Economics to understand } \\
\text { costs of staying put }\end{array}$ & $\begin{array}{l}\text { Economics to better understand } \\
\text { the role of the informal } \\
\text { economy, how money and } \\
\text { labor are actually used }\end{array}$ & $\begin{array}{l}\text { Economics to better enumerate } \\
\text { buffers and understand the } \\
\text { implications of their stocks and } \\
\text { flows across the system }\end{array}$ & $\begin{array}{l}\text { Economics to better understand the } \\
\text { magnitude and impacts of subsidies }\end{array}$ \\
\hline $\begin{array}{l}\text { Policy studies to address } \\
\text { justice and ethics of the } \\
\text { burdens of attachment }\end{array}$ & $\begin{array}{l}\text { Policy studies to determine how } \\
\text { innovation and adaptation can } \\
\text { be fostered and promoted }\end{array}$ & $\begin{array}{l}\text { Policy studies to assess how buffers } \\
\text { are viewed by policy-makers for } \\
\text { both intended and unintended } \\
\text { consequences }\end{array}$ & $\begin{array}{l}\text { Policy studies to consider implications of } \\
\text { how the system currently works and is } \\
\text { managed, together with ideas for how it } \\
\text { might be managed better }\end{array}$ \\
\hline $\begin{array}{l}\text { Public health studies to } \\
\text { consider health impacts } \\
\text { of attachment }\end{array}$ & & $\begin{array}{l}\text { Public health studies to consider the } \\
\text { consequences of "health buffering" }\end{array}$ & $\begin{array}{l}\text { Public health studies to consider otherwise } \\
\text { hidden impacts }\end{array}$ \\
\hline
\end{tabular}


Table 4 Policy implications of better differentiating attachment, alternatives, and buffering

\begin{tabular}{|c|c|c|c|c|}
\hline & Attachment & Alternatives & Buffering & Overall \\
\hline $\begin{array}{l}\text { How policy actions } \\
\text { can help }\end{array}$ & $\begin{array}{l}\text { Promote the commitment to } \\
\text { place, identity, well-being } \\
\text { Offer opportunities in } \\
\text { communities_e.g., training } \\
\text { programs, college degree } \\
\text { programs (where students } \\
\text { do not have to leave) }\end{array}$ & $\begin{array}{l}\text { Promote generalist skills that } \\
\text { can be used in the community } \\
\text { Allow flexibility in subsistence } \\
\text { activities } \\
\text { Provide services and tools that } \\
\text { facilitate access to alternatives, } \\
\text { e.g., hunting equipment of } \\
\text { various kinds (hunter support) }\end{array}$ & $\begin{array}{l}\text { Recognize buffers and their role } \\
\text { Replenish buffers when possible, } \\
\text { preventing long-term problems }\end{array}$ & $\begin{array}{l}\text { Train for flexibility and } \\
\text { local needs } \\
\text { Understand how the } \\
\text { system works, how } \\
\text { its parts connect } \\
\text { Manage the whole system, } \\
\text { not separate pieces, } \\
\text { including across scales } \\
\text { Empower communities to } \\
\text { develop comprehensive } \\
\text { strategies, with resources } \\
\text { to achieve them }\end{array}$ \\
\hline $\begin{array}{l}\text { How policy actions } \\
\text { can hurt }\end{array}$ & $\begin{array}{l}\text { Make the acquisition of useful } \\
\text { skills difficult, fostering } \\
\text { negative attachment } \\
\text { Rely on attachment to shift } \\
\text { burden of change to } \\
\text { community residents }\end{array}$ & $\begin{array}{l}\text { Promote over-specialization and } \\
\text { thus outmigration or idleness } \\
\text { Continue to manage subsistence } \\
\text { on species-by-species basis }\end{array}$ & $\begin{array}{l}\text { Ignore buffers and their role } \\
\text { Fail to replenish buffers when } \\
\text { possible, leading to long-term } \\
\text { problems } \\
\text { Overlook emerging problems }\end{array}$ & $\begin{array}{l}\text { Promote over-specialization } \\
\text { so skills may be useless in } \\
\text { home community } \\
\text { Manage parts separately, } \\
\text { ignoring how one affects } \\
\text { others } \\
\text { Fund community projects one } \\
\text { at a time, with no flexibility } \\
\text { to shift funds }\end{array}$ \\
\hline
\end{tabular}

coming decades. A better understanding of how communities function and respond to change today will help in developing better policies for the future.

Impacts directly attributable to drivers such as climate change provide insight into the mechanisms of humanenvironment interactions. But such simple cases may also be special cases. Perhaps, more common are those, such as the communities of Arctic Alaska explored here, where the pathway from stimulus to response involves a variety of influences, each of which may have different implications for research and policy. Attachment, alternatives, and buffering demonstrate the kinds of factors that may be at play in determining human responses to change. They illustrate why it is important to go beyond system-level notions of resilience and adaptation, to seek explanations and to make distinctions among those explanations so we can better understand what is happening, why, and how further intervention can help or hinder.

Acknowledgements We thank our colleagues on the Sustainable Futures North project as well as others with whom we have discussed many of the ideas herein over the years. We are grateful to the two reviewers of the manuscript who provided constructive comments that helped improve the original version.

Funding This study was funded by the National Science Foundation (USA), grants \# 1262722, 1263606, 1263853, and 1263650, and the National Institute for Food and Agriculture, U.S. Department of Agriculture, grant \#201402378, for which we are grateful.

\section{Compliance with ethical standards}

Conflict of interest The authors declare that they have no conflict of interest.
Open Access This article is distributed under the terms of the Creative Commons Attribution 4.0 International License (http:// creativecommons.org/licenses/by/4.0/), which permits unrestricted use, distribution, and reproduction in any medium, provided you give appropriate credit to the original author(s) and the source, provide a link to the Creative Commons license, and indicate if changes were made.

\section{References}

Adger WN (2016) Place, well-being, and fairness shape priorities for adaptation to climate change. Glob Environ Chang 38:A1-A3. https://oi.org/10.1016/j.gloenvcha.2016.03.009

Adger WN, Arnell NW, Tompkins EL (2005) Successful adaptation to climate change across scales. Glob Environ Chang 15:77-86. https://doi.org/10.1016/j.gloenvcha.2004.12.005

Adger, W.N., Pulhin, J.M., Barnett, J., Dabelko, G.D., Hovelsrud, G.K., Levy, M., Oswald Spring, Ú., and Vogel, C.H. (2014) Human security. In: Field, C.B., V.R. Barros, D.J. Dokken, K.J. Mach, M.D. Mastrandrea, T.E. Bilir, M. Chatterjee, K.L. Ebi, Y.O. Estrada, R.C. Genova, B. Girma, E.S. Kissel, A.N. Levy, S. MacCracken, P.R. Mastrandrea, and L.L. White, eds. Climate change 2014: impacts, adaptation, and vulnerability. Part A: Global and sectoral aspects. Contribution of working group II to the Fifth Assessment Report of the Intergovernmental Panel on Climate Change. Cambridge, UK: Cambridge University Press, pp. 755-791

ADHSS (Alaska Department of Health and Social Services) (2016) Health Indicator Report of Obesity-Adults (18+) Retrieved June 20, 2016, from http://ibis.dhss.alaska.gov/indicator/view/Obe. AK US time.html

Alexander DE (2013) Resilience and disaster risk reduction: an etymological journey. Nat Hazards Earth Syst Sci 13:2707-2716. https:// doi.org/10.5194/nhess-13-2707-2013

Allen J, Mohatt GV, Fok CCT, Henry D, Burkett R (2014) A protective factors model for alcohol abuse and suicide prevention among Alaska Native youth. Am J Community Psychol 54(1-2):125139. https://doi.org/10.1007/s10464-014-9661-3 
Allen J, Beehler S, Gonzalez J (2016) Suicide and substance use disorder prevention for rural American Indian and Alaska Native youth. In: Crockett LJ, Carlo G (eds) Rural ethnic minority youth and families in the United States. Springer, Cham, Switzerland, pp 185-201

Allison HE, Hobbs RJ (2004) Resilience, adaptive capacity, and the "lock-in trap" of the Western Australian agricultural region. Ecol Soc 9(1):3-27

Arctic Council (2016) Arctic Resilience Report. Stockholm Environment Institute and Stockholm Resilience Centre. Stockholm, Sweden

Barnett J, O’Neill S (2010) Maladaptation. Glob Environ Chang 20(2): 211-213. http://dx.doi.org/10.1016/j.gloenvcha.2009.11.004

Bates DG (2004) Human adaptive strategies: ecology, culture, and politics, 3rd edn. Pearson, Boston

Bateson G (1967) Cybernetic explanation. Am Behav Sci 10:29-29

Bennett JW (1976) The ecological transition: cultural anthropology and human adaptation. Pergamon, New York

Bennett JW (1996) Human ecology as human behavior. Transaction Publishers, New Brunswick

Biermann F, Boas I (2010) Preparing for a warmer world: towards a global governance system to protect climate refugees. Glob Environ Polit 10(1):60-88. https://doi.org/10.1162/glep.2010.10.1.60

Black R, Adger WN, Arnell NW, Dercon S, Geddes A, Thomas DSG (2011) The effect of environmental change on human migration. Glob Environ Chang 21(Supplement 1):S3-S11. https://oi.org/10. 1016/j.gloenvcha.2011.10.001

Brand FS, Jax K (2007) Focusing the meaning (s) of resilience: resilience as a descriptive concept and a boundary object. Ecol Soc 12:23

Brinkman T, Maracle KB, Kelly J, Vandyke M, Firmin A, Springsteen A (2014) Impact of fuel costs on high-latitude subsistence activities. Ecol Soc 19(4):18. https://doi.org/10.5751/ES-06861-190418

Bronen R (2009) Forced migration of Alaskan indigenous communities due to climate change: creating a human rights response. In: OliverSmith A, Shen X (eds) Linking environmental change, migration and social vulnerability. Bonn, UNU Institute for Environment and Human Security, pp 68-73

BurnSilver S, Magdanz J, Stotts R, Berman M, Kofinas G (2016) Are mixed economies persistent or transitional? Evidence using social networks from Arctic Alaska. Am Anthropol 118(1):121-129. https://doi.org/10.1111/aman.12447

Byron R (ed) (2003) Retrenchment and regeneration in rural Newfoundland. University of Toronto Press, Toronto

CDC (Centers for Disease Control and Prevention) (2003) Diabetes prevalence among American Indians and Alaska Natives and the overall population-United States, 1994-2002. Morb Mortal Wkly Rep $52(30)$

Carr ER (2005) Placing the environment in migration: environment, economy, and power in Ghana's Central Region. Environ Plan A 37:925-946. https://doi.org/10.1068/a3754

Chapin FS III, Trainor SF, Cochran P, Huntington H, Markon C, McCammon M, McGuire AD, Serreze M (2014) Alaska. In: Melillo JM, Richmond TC, Yohe GW (eds) Climate change impacts in the United States: the Third National Climate Assessment. Washington, D.C, U.S. Global Change Research Program, pp 514-536. https://doi.org/10.7930/J00Z7150

Cumming GS, Collier J (2005) Change and identity in complex systems. Ecol Soc 10(1):29

Davidson DJ (2010) The applicability of the concept of resilience to social systems: some sources of optimism and nagging doubts. Soc Nat Resour 23:1135-1149. https://doi.org/10.1080/ 08941921003652940

Diener E (2009) The science of well-being: the collected works of Ed Diener. Springer, Cham, Switzerland

Entwisle B, Williams NE, Verdery AM, Rindfuss RR, Walsh SJ, Malanson GP, Mucha PJ, Frizzelle BG, McDaniel PM, Yao X, Heumann BW, Prasartkul P, Sawangdee Y, Jampaklay A (2016) Climate shocks and migration: an agent-based modeling approach.
Popul Environ 38(1):47-71. https://doi.org/10.1007/s11111-0160254-y

Fazey, I., Moug, P., Allen, S., Beckmann, K., Blackwood, D., Bonaventura, M., Burnett, K., Danson, M., Falconer, R., Gagnon, A.S., Harkness, R., Hodgson, A. Holm, L., Irvine, K.N., Low, R., Lyon, C., Moss, A., Moran, C., Naylor, L., O'Brien, K., Russell, S., Skerratt, S., Rao-Williams, J., and Wolstenholme, R. (2017) Transformation in a changing climate: a research agenda. Clim Dev 0:1-21. https://doi.org/10.1080/17565529.2017.1301864

Fazzino D, Loring PA (2009) From crisis to cumulative effects: food security challenges in Alaska. NAPA Bull 32(1):152-177. http:// doi.org/10.1111/j.1556-4797.2009.01033.x

Feola G (2015) Societal transformation in response to global environmental change: a review of emerging concepts. Ambio 44:376

Ford JD, Berrang-Ford L, Bunce A, McKay C, Irwin M, Pearce T (2015) The status of climate change adaptation in Africa and Asia. Reg Environ Chang 15:801-814. https://doi.org/10.1007/s10113-0140648-2

Fussell E, Elliott JR (2009) Introduction: social organization of demographic responses to disaster: studying population-environment interactions in the case of Hurricane Katrina. Org Environ 22:379394. https://doi.org/10.1177/1086026609347181

Gallopín GC (2006) Linkages between vulnerability, resilience, and adaptive capacity. Glob Environ Chang 16(3):293-303. https://doi.org/ 10.1016/j.gloenvcha.2006.02.004

Gerlach SC, Loring PA, Turner AM, Atkinson DE (2011) Food systems, climate change, and community needs. In: Lovecraft AL, Eicken $\mathrm{H}$ (eds) North by 2020. University of Alaska Press, Fairbanks, pp 111134

Grumbine RE (2014) Assessing environmental security in China. Front Ecol Environ 12(7):403-411. https://doi.org/10.1890/130147

Hamilton LC (2007) Climate, fishery and society interactions: observations from the North Atlantic. Deep Sea Res II 54(23-26):29582969. https://doi.org/10.1016/j.dsr2.2007.08.020

Hamilton LC, Haedrich RL (1999) Ecological and population changes in fishing communities of the North Atlantic Arc. Polar Res 18(2): 383-388. http://dx.doi.org/10.3402/polar.v18i2.6599

Hamilton LC, Seyfrit CL (1994) Female flight? Gender balance and outmigration by Native Alaskan villagers. Arctic Med Res 53:189-193

Hamilton LC, Colocousis CR, Johansen STF (2004) Migration from resource depletion: the case of the Faroe Islands. Soc Nat Resour 17(5):443-453. http://dx.doi.org/10.1080/08941920490430232

Hamilton LC, Saito K, Loring PA, Lammers RA, Huntington HP (2016) Climigration? Population and climate change in Arctic Alaska. Popul Environ 38:115-133. https://doi.org/10.1007/s11111-0160259-6

Haynie AC, Huntington HP (2016) Strong connections, loose coupling: the influence of the Bering Sea ecosystem on commercial fisheries and subsistence harvests in Alaska. Ecol Soc 21(4):6. https://doi.org/ 10.5751/ES-08729-210406

Holling CS (1973) Resilience and stability of ecological systems. Annu Rev Ecol Syst 4:1-23

Howe EL, Huskey L, Berman MD (2014) Migration in Arctic Alaska: empirical evidence of the stepping stones hypothesis. Migr Stud 2(1):97-123. https://doi.org/10.1093/migration/mnt017

Hunter LM (2005) Migration and environmental hazards. Popul Environ 26:273-302. https://doi.org/10.1007/s11111-005-3343-x

Hunter LM, Luna JK, Norton RM (2015) Environmental dimensions of migration. Annu Rev Sociol 41(1):377-397. https://doi.org/10. 1146/annurev-soc-073014-112223

Huntington HP, Hamilton LC, Nicolson C, Brunner R, Lynch A, Ogilvie AEJ, Voinov A (2007) Toward understanding the human dimensions of the rapidly changing arctic system: insights and approaches from five HARC projects. Reg Environ Chang 7(4):173-186. https://doi.org/10.1007/s10113-007-0038-0 
Huntington HP, Goodstein E, Euskirchen E (2012) Towards a tipping point in responding to change: rising costs, fewer options for arctic and global societies. Ambio 41:66-74. https://doi.org/10.1007/ s13280-011-0226-5

Huntington HP, Quakenbush LT, Nelson M (2016) Effects of changing sea ice on marine mammals and subsistence hunters in northern Alaska from traditional knowledge interviews. Biol Lett 12: 20160198. https://doi.org/10.1098/rsbl.2016.0198

Huntington, HP, Begossi, A, Gearheard, S, Kersey, B, Loring, P, Mustonen, T, Paudel, PK, Silvano, RAM, Vave, R (2017) How small communities respond to environmental change: patterns from tropical to polar ecosystems. Ecol Soc 22(3):9

Huskey L, Berman M, Hill A (2004) Leaving home, returning home: migration as a labor market choice for Alaska Natives. Ann Reg Sci 38:75-92. https://doi.org/10.1007/s00168-003-0141-1

Kates RW (2011) What kind of a science is sustainability science? Proc Natl Acad Sci 108(49):19449-19450. https://doi.org/10.1073/pnas. 1116097108

Kofinas, G.P., BurnSilver, S., Magdanz, J., Stotts, R., and Okada, M. (2016) Subsistence sharing networks and cooperation: Kaktovik, Wainwright, and Venetie, Alaska. BOEM Report 2015-023DOI; AFES Report MP 2015-02. Fairbanks: School of Natural Resources and Extension, University of Alaska Fairbanks

Kuhnlein HV, Receveur O, Soueida R, Egeland GM (2004) Arctic indigenous peoples experience the nutrition transition with changing dietary patterns and obesity. J Nutr 134:1447-1453

Loring PA (2013) Are we acquiescing to climate change? Social and environmental justice considerations for a changing Arctic. In: Mueter FJ, Dickson DMS, Huntington HP, Irvine JR, Logerwell EA, MacLean SA, Quakenbush LT, Rosa C (eds) Responses of Arctic marine ecosystems to climate change. Alaska Sea Grant, University of Alaska, Fairbanks. https://doi.org/10.4027/ramecc. 2013.01

Loring PA, Gerlach SC (2009) Food, culture, and human health in Alaska: an integrative health approach to food security. Environ Sci Policy 12:466-478. https://doi.org/10.1016/j.envsci.2008.10. 006

Loring PA, Gerlach SC (2015) Searching for progress on food security in the North American North: a research synthesis and meta-analysis of the peer-review literature. Arctic 68(3):380-392. 10.14430/ $\operatorname{arctic} 4509$

Loring PA, Gerlach SC, Huntington HP (2013) The new environmental security: linking food, water, and energy for integrative and diagnostic social-ecological research. J Agric Food Syst Community Dev 3:55-61. https://doi.org/10.5304/jafscd.2013.034.005

Loring PA, Gerlach SC, Penn HJ (2016) "Community work" in a climate of adaptation: responding to change in rural Alaska. Hum Ecol 44(1):119-128. https://doi.org/10.1007/s10745-015-9800-y

MacDonald M, Sinclair P, Walsh D (2012) Labour migration and mobility in Newfoundland: social transformation and community in three rural areas. In: Parkins JR, Reed MG (eds) Social transformation in rural Canada: community, culture and collective action. University of British Columbia Press, Vancouver, pp 110-130

Magdanz, J. S., Utermohle, C. J., and Wolfe, R. J. (2002) The production and distribution of wild food in Wales and Deering, Alaska. Technical Paper 259. Juneau: Alaska Department of Fish and Game, Division of Subsistence

Marina A, Asbjornsen H, Baker LA, Brozovic N, Drinkwater LE, Drzyzga SA (2011) Research on coupled human and natural systems (CHANS): approach, challenges, and strategies. Bull Ecol Soc Am 92:218-228

Marino E (2015) Fierce climate, sacred ground. University of Alaska Press, Fairbanks

Markon, C.J., Trainor, S.F., and Chapin III, F.S. (2012) The United States National Climate Assessment-Alaska Technical Regional Report.
U.S. Geological Survey Circular 1379. Anchorage: US Geological Survey

Maxwell DG, Ahiadeke C, Levin C, Armar-Klemesu M, Zakariah S, Lamptey GM (1999) Alternative food-security indicators: revisiting the frequency and severity of 'coping strategies'. Food Policy 24: 411-429. https://doi.org/10.1016/S0306-9192(99)00051-2

McClanahan, T.R., and Cinner, J. (2011) Adapting to a changing environment: confronting the consequences of climate change: confronting the consequences of climate change. Oxford University Press

McGreavy, B. (2015) Resilience as discourse. Environ Commun 0:1-18. doi: https://doi.org/10.1080/17524032.2015.1014390

McLeman R (2014) Climate and human migration: past experiences, Future Challenges. Cambridge University Press, New York, NY

McLeman R, Smit B (2006) Migration as an adaptation to climate change. Clim Chang 76(112):31153. https://doi.org/10.1007/ s10584-005-9000-7

Myers N (2002) Environmental refugees: a growing phenomenon of the 21st century. Philos Trans R Soc Lond Ser B Biol Sci 357:609-613. https://doi.org/10.1098/rstb.2001.0953

Oliver-Smith A (2013) Disaster risk reduction and climate change adaptation: the view from applied anthropology. Hum Organ 72:275282. http://dx.doi.org/10.1111/napa.12089

Penn HJF, Gerlach SC, Loring PA (2016) Seasons of stress: understanding the dynamic nature of people's ability to respond to change and surprise. Weather Clim Soc. https://doi.org/10.1175/WCAS-D-150061.1

Rogers, S. (2015) No more free shipping to most Nunavut, Nunavik communities: Amazon Nunatsiaq Online, April 10. http://www. nunatsiaqonline.ca/stories/article/65674no_more_free_shipping to most nunavut nunavik communities amazon/

Serreze MC, Barry RG (2011) Processes and impacts of Arctic amplification: a research synthesis. Glob Planet Chang 77:85-96. https:// doi.org/10.1016/j.gloplacha.2011.03.004

Standish RJ, Hobbs RJ, Mayfield MM, Bestelmeyer BT, Suding KN, Battaglia LL, Eviner V, Hawkes CV, Temperton VM, Cramer VA, Harris JA, Funk JL, Thomas PA (2014) Resilience in ecology: abstraction, distraction, or where the action is? Biol Conserv 177:4351. https://doi.org/10.1016/j.biocon.2014.06.008

Steevenson LJ (2004) A study of the revival of Priorat and its contemporary challenges. J Wine Res 15:65-84. https://doi.org/10.1080 0957126042000300353

Thornton TF, Manasfi N (2010) Adaptation-genuine and spurious: demystifying adaptation processes in relation to climate change. Environ Soc Adv Res 1:132-155. http://dx.doi.org/10.3167/ares. 2010.010107

Trentelman CK (2009) Place attachment and community attachment: a primer grounded in the lived experience of a community sociologist. Soc Nat Resour 22(3):191-210. https://doi.org/10.1080/ 08941920802191712

Turner N, Gregory R, Brooks C, Failing L, Satterfield T (2008) From invisibility to transparency: identifying the implications. Ecol Soc $13: 7$

UNDP (2010) Mobility and migration: a guidance note for human development report teams. United Nations Development Programme

Vayda, A.P., and Walters, B.B. (2011) Causal explanation for social scientists: a reader. AltaMira Press

Voinov A, Bromley L, Kirk E, Korchak A, Farley J, Moiseenko T, Krasovskaya T, Makarova Z, Megorski V, Selin V, Kharitonova G, Edson R (2004) Understanding human and ecosystem dynamics in the Kola Arctic: a participatory integrated study. Arctic 57(4):375388. http://dx.doi.org/10.14430/arctic515

Walker B, Salt D (2012) Resilience practice: building capacity to absorb disturbance and maintain function. Island Press, Washington, DC 
Walker B, Gunderson LH, Kinzig A, Folke C, Carpenter SR, Schultz L (2006) A handful of heuristics and some propositions for understanding resilience in social-ecological systems. Ecol Soc 11:13

WCED (World Commission on Environment and Development) (1987)

Our common future. Oxford University Press, Oxford
Zak, A. (2015) Amazon Prime eases rural Alaska's pricey shipping woes. Alaska Dispatch News, December 15. http://www.adn.com/article/ 20151219/amazon-prime-eases-rural-alaskas-pricey-shipping-woes 